\title{
Seismic capacity evaluation of the damaged reinforced concrete building during Palu earthquake 2018
}

\author{
Fajar Nugroho ${ }^{1,2^{*}}$ \\ ${ }^{1}$ Doctoral Student of Civil Engineering Department, Andalas University, Padang, 25163, Indonesia \\ ${ }^{2}$ Civil Engineering Department, Padang Institute of Technology, Padang, 25143, Indonesia
}

\begin{abstract}
This paper presents an evaluation of the seismic capacity of the Dean Building of The Faculty of Social and Political Science of Tadulako University due to the Palu Earthquake 2018. The building was built in 2016 and went into use in 2017. The building is made from a reinforced concrete frame consisting of three floors and collapsed after the earthquake. Data for the analysis are taken from the Detail Engineering Design of the Dean Building of The Faculty of Social And Political Science of Tadulako University in 2015. Seismic capacity evaluated based on Standard for Seismic Evaluation of Existing Reinforced Concrete Buildings issued by the Japan Country. The analysis are done on the 1st-floor structure because the most significant sliding force happens on the first floor. Seismic capacity is invoked in the form of a link between the lateral strength and the ductility index. By using Japanese standards, the building's seismic capacity is relatively small in withstanding the earthquake load and collapsed the building. Based on observations in the field by conducting non-destructive testing using hammer tests, the concrete material had relatively low quality and a failure to connect the column beams by insufficiently reintegrating and resulted in a collapse of the building.
\end{abstract}

\section{Introduction}

Geologically, Indonesia locates in a disaster-prone area. Almost all Indonesian territory, such as Sumatera, Java, Bali, Nusa Tenggara, Sulawesi, and Papua, are prone to earthquakes followed by a tsunami. The data recorded earthquakes with the magnitude of $7 \mathrm{SR}$ above are Aceh earthquake magnitude 9,1 followed by tsunami in 2004; Nias magnitude 8,6 earthquake in 2005; Pangandaran magnitude 7,7 earthquake followed by tsunami in 2006; Bengkulu magnitude 8,5 earthquake in 2007; Simelue magnitude 7,4 earthquake in 2008; Padang Pariaman magnitude 7,6 earthquake in 2009; Mentawai magnitude 7,8 earthquake in 2010; Aceh magnitude 8,6 earthquake in 2012, and Ternate magnitude 7,1 earthquake in 2014 [1]. In 2018, Lombok magnitude 6,4 earthquakes in July and magnitude 6,9 in September. In September 2018 magnitude 7,5 earthquake followed by a tsunami occurred in Palu, Central Sulawesi [2].

Fig. 1 shows scattered Palu earthquakes with different magnitude. The Meteorology Climatology and Geophysics Agency of Indonesia (BMKG) records Donggala-Palu Earthquake occurring on September 28, 2018, at 06:02 p.m. WITA (Middle Indonesian Time) with hypocentre $10 \mathrm{~km}$ and magnitude 7,5. From 06:27 p.m., a tsunami occurred as far as about $700 \mathrm{~m}$ from the coastline. The earthquake that followed by the tsunami caused infrastructure damage and caused fatalities. As of October 21, 2018, The National Disaster Management Agency of Indonesia (BNPB) recorded 2.256 people died, 1.309 people were declared missing, 4.162 people were injured, and 223.751 people had been displaced at 122 areas. Damage covered 68.451 housing units, 327 house of worship units, 265 schools, 78 office units, 362 shops, 168 cracked roads, and 7 bridges. The financial loss due to the earthquakes, tsunamis, and liquefaction reached over 13,82 trillion rupiah [3].

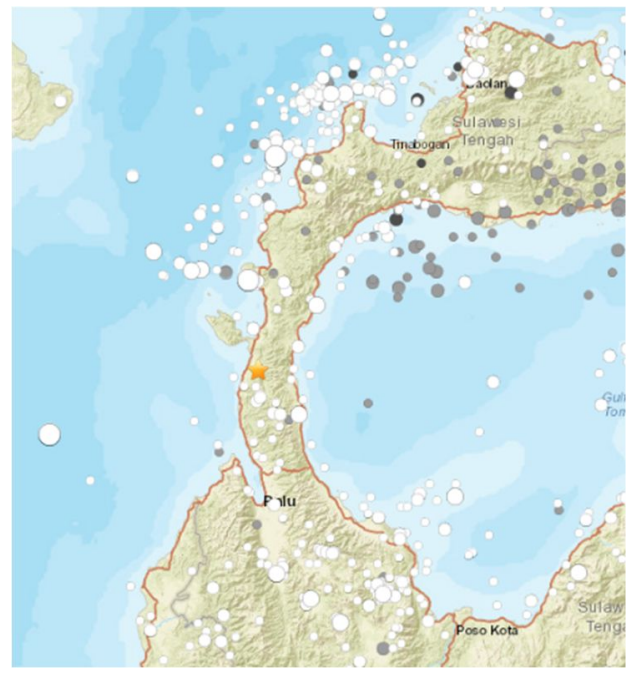

Fig. 1. Map of Palu Earthquake Distribution 2018 [2]

The post-earthquake observation was carried out in the Donggala Regency and Palu City, as shown in Fig. 1. The object of observation was damage in the skeletal structure of medium-grade concrete. In Palu city, the observation was conducted at Tadulako University, included two collapsed buildings: the Dean Building of the Faculty of Social and Political Sciences (FISIP), and

${ }^{1}$ Corresponding author: fajarnugroho@itp.ac.id 
the Faculty of Forestry Lecture Building. A seismic capacity evaluation was performed on The Dean Building of the Faculty of Social and Political Sciences that was analyzed based on the Standard for Seismic Evaluation of Existing Reinforced Concrete Buildings issued by the Japanese State.

\section{Literature review}

\subsection{State of the art}

\subsubsection{Earthquake}

Earthquakes that occur in general are caused by the release of energy produced by the pressure performed by the moving earth plates. The longer the pressure grows and eventually reaches the condition where the pressure cannot be withheld again by the edges of the plate. The released energy propagates through the soil in the form of vibration waves. The vibration waves that are up to the Earth's surface are called earthquakes. The substantial damage caused by earthquakes is influenced by several factors, such as earthquake strength, hypocentre location, soil structure, and building structure.

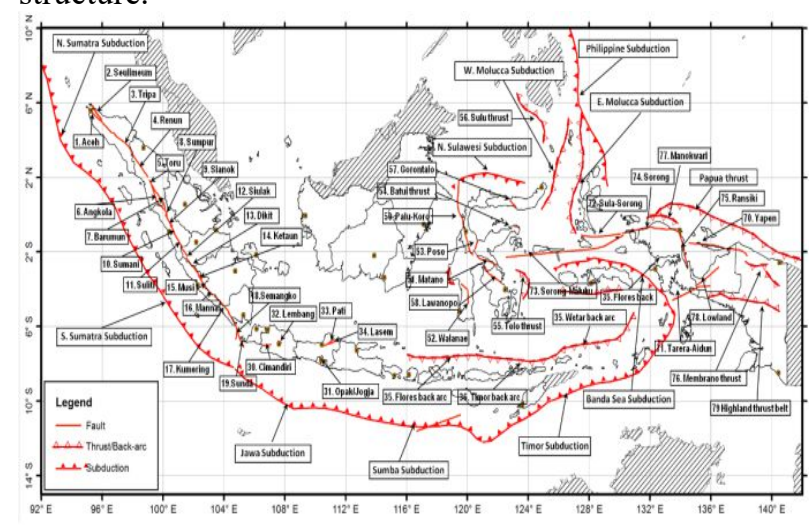

Fig. 2. Tectonic Maps and Active Faults in Indonesia [4]

\subsubsection{The principle of earthquake-resistant buildings}

According to the Technical Guidelines of the House and Earthquake Resistant Buildings [5], that the minimum security level for buildings and residences, which included in the category of earthquake-resistant buildings, should meet the following conditions :

a. When affected by a weak earthquake, the building does not suffer any damage at all.

b. If there is a moderate earthquake, the building may be damaged on non-structural elements, but it should not be damaged on structural elements.

c. When hit by a powerful earthquake, the building should not collapse either partially or entirely. The building may not suffer damage that can not be repaired the building may suffer damage, but damage should be quickly repaired so that the building can function again.

\subsubsection{Seismic capacity}

One of the research on the method of evaluation of the seismic capacity of the existing reinforced concrete building is by Maidiawati [6]. In the research, a method was developed to evaluate the seismic capacity of the existing reinforced concrete building by applying a diagonal strut model to account for the influence of brick walls in the skeletal structure. In this model of diagonal strut, width is given as a high function of contact between the wall and the frame structure that can be solved with a voltage equilibrium equality press and lateral displacement on the contact area. Lateral strength and stiffness of walls are obtained based on diagonal strut widths. The diagonal strut model has been verified with the test result of skeletal structures with brick walls. Get matched results between structural testing and model analysis results for lateral rigidity and strength as well as brick wall ductility. Therefore, the model of diagonal strut can be applied to evaluate the seismic capacity of the existing reinforced concrete building in the city of Padang. This study evaluated the seismic capacity of a reinforced concrete building 2 (two) floors to without and by taking into account the influence of brick walls by applying a diagonal model strut to the brick wall. While the seismic capacity of buildings without brick wall influences are evaluated according to Japanese standards. As a result, the brick walls in skeletal structures can increase the seismic capacity of reinforced concrete buildings significantly.

\subsection{Earthquake and tsunami disaster in Palu}

During the year 2018 in Indonesia occurred 23 incidents of big earthquakes and 1 occurrence of earthquakes followed by tsunami [7]. The earthquake disaster caused casualties of 572 people casualties and lost; 2.001 people were injured, and 483.399 people were affected and displaced. In addition, 226.667 units of houses and 1.154 units of public facilities suffered damage. The earthquake and tsunami that occurred in Palu, Central Sulawesi inflicting casualties of 3.475 people died and lost, 4.438 people injured, and 221.450 people were affected and displaced. As well as as many as 68.451 units of houses and 614 units of public facilities suffered damage.

The Palu earthquake occurred due to certain phenomena; there is land movement and lasts for days with different scales with the following explanation:

1. Palu earthquake occurs in the area of Palu and Donggala that consists of three areas of tectonic plates. This resulted in frequent shifting and ground movements, notably the Palu being the intersection of the Indian Ocean and the Pacific Ocean.

2. According to the Research of Hamilton [8], there are 3 tectonic faults called the Palukoro fault, the Saddang fault, and Walinae faults. This fault is vertical and is in the northern area, while the horizontal fault is located in the western area with speed higher than the Sumatra area of 14-17 mm per year. 
3. The Palukoro faulting is a fault that will always be active. This fault will always be shifted and is not known when it will cause small or large friction.

4. Occurrence of liquefaction or soil liquefaction during the earthquake. The liquefaction is an event in which water enters into contour of soil, and form into mud or texture into liquid. So the soil and contours shifted and eventually led to landslides that caused the Tsunami. Palu and Donggala have sand soil and facilitate the water to enter and cause liquefaction. This is what causes Palu and Donggala to experience earthquake and tsunami disasters.

\subsection{Seismic capacity evaluation method}

The seismic capacity of buildings is a representation of the ability to build structures to withstand lateral forces that will occur against buildings. The overall capacity of a structure depends on its strength and ability to deform in existing elements of the structure.

To calculate and evaluate the strength and ductility of reinforced concrete buildings, refer to the book Standard For Seismic Evaluation Of Existing Reinforced Concrete Buildings, published by The Japan Building Disaster Prevention Association [9]. Based on this standard, there are three stages or methods of evaluation, namely evaluation level one, level two, and level three.

In the level one evaluation method, the vertical structure is classified into three types, as described in Table 1. At level one, the evaluation is still simple because there is no review for the detail of the structure so that the data obtained from this level is not very accurate.

Table 1. Classification of vertical structures

\begin{tabular}{|l|l|}
\hline $\begin{array}{l}\text { Structure } \\
\text { Vertical }\end{array}$ & \multicolumn{1}{|c|}{ Definition } \\
\hline Column & Columns that have $\mathrm{h}_{0} / \mathrm{D}>2$ \\
\hline Short Column & Columns that have $\mathrm{h}_{0} / \mathrm{D} \leq 2$ \\
\hline Wall & $\begin{array}{l}\text { Walls that are not restricted by } \\
\text { columns }\end{array}$ \\
\hline
\end{tabular}

In the second level evaluation method, the vertical elements are divided into five categories, as described in Table 2.

The seismic capacity index value is expressed in the relationship between the strength index value $(\mathrm{C})$ and the ductility index (F), as shown in Fig. 3. At this second level, details of the structure are reviewed, and data obtained has been more accurate, the evaluation at this level is enough to represent the capacity of the ductility capacity of the building.

The vertical elements of the building should be taken into account to increase the strength and rigidity of the building; the elements to be taken into account are columns and walls. The column element that is calculated in the evaluation consists of short columns $\left(\mathrm{h}_{0}\right)$ and a long column $\left(\mathrm{H}_{0}\right)$. The short column is a column filled by a window or door frame. The long column is a vertical element that is fully filled by the wall as well as a stand-alone column. The existence of long columns and short columns affect the ultimate moment of the building so that its existence should be noticed in detail.

Table 2. Categorizing of vertical elements based on the type of damage in the second level evaluation calculation

\begin{tabular}{|l|l|}
\hline Structure Vertical & \multicolumn{1}{|c|}{ Definition } \\
\hline Sliding Wall & $\begin{array}{l}\text { Walls that have a sliding breakdown } \\
\text { before experiencing bending } \\
\text { flexibility }\end{array}$ \\
\hline Bending Wall & $\begin{array}{l}\text { Walls that have been flexed in the dark } \\
\text { before sliding damage }\end{array}$ \\
\hline Sliding Column & $\begin{array}{l}\text { Columns that have a sliding } \\
\text { breakdown before experiencing } \\
\text { bending flexibility }\end{array}$ \\
\hline Bending Column & $\begin{array}{l}\text { Columns that have a flexible slop } \\
\text { before experiencing a sliding defect }\end{array}$ \\
\hline Weak Column & $\begin{array}{l}\text { The ho/ D column has the same or } \\
\text { small value of 2 and has a sliding } \\
\text { defect before having a flexible fatigue }\end{array}$ \\
\hline
\end{tabular}

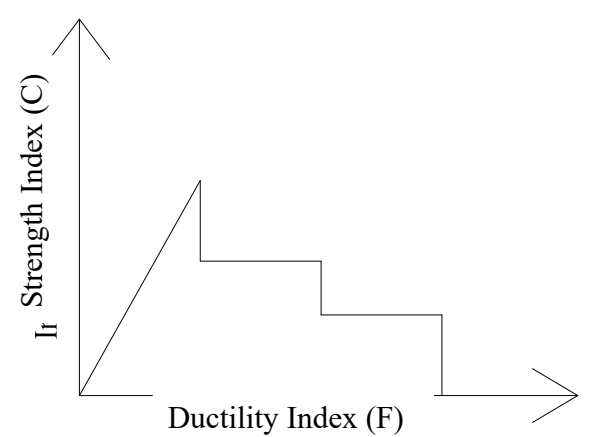

Fig. 3. The Relationship Curve of Strength Index (C) and the Ductility Index (F)

The column shear force on ultimate bending $\left(\mathrm{Q}_{\mathrm{mu}}\right)$

$$
\mathrm{Q}_{\mathrm{mu}}=\frac{2 \mathrm{M}_{\mathrm{u}}}{\mathrm{h}_{0}}
$$

The ultimate shear strength of the structure $\left(\mathrm{Q}_{\mathrm{su}}\right)$

$$
\mathrm{Q}_{\mathrm{su}}=\left\{\frac{0,053 \cdot \mathrm{P}_{\mathrm{t}}^{0,23}\left(18+\mathrm{F}_{\mathrm{c}}\right)}{\frac{\mathrm{M}}{\mathrm{Q} \cdot \mathrm{d}}+0,12}+0,85 \sqrt{\mathrm{P}_{\mathrm{w}} \cdot \mathrm{S} \cdot \sigma_{\mathrm{w}}}+0,1 \sigma_{0}\right\} \mathrm{b} \cdot \mathrm{j}
$$

The collapse of a building is determined by the ultimate shear strength $\left(\mathrm{Q}_{\mathrm{su}}\right)$ and the ultimate flexural strength $\left(\mathrm{Q}_{\mathrm{mu}}\right)$. If the $\mathrm{Q}_{\mathrm{su}} / \mathrm{Q}_{\mathrm{mu}}<1$, it is mean the collapsed form of the building is a shear collapse. The shape of the collapse of a building is an important point to calculate the ductility of a building. According to The Japan Building Disaster Prevention Association [9], the collapsed form of a building is used to see the ratio of building strength index. The strength index (C) in the second level calculation method can be calculated by the following equation :

$$
\mathrm{C}=\frac{\mathrm{Q}_{\mathrm{u}}}{\Sigma \mathrm{W}}
$$

Definition of ductility is the ability of a building structure to experience large post-elastic deviations repeatedly and cyclic due to the earthquake loads that cause of the first yield stage, while maintaining 
sufficient strength and rigidity so that the structure of the building remains to stand, even though it is already in critical condition of collapse. Ductility index, F, is a certain deformability which is calculated according to structural specifications based on stiffness, strength, dimensions [9]. The ductility index of the shear column is calculated using equation (4) based on the angle when the deformation in the building occurs.

$$
F=1+0,27 \frac{R_{s u}-R_{250}}{R_{y}-R_{250}}
$$

The ductility index of the bending column can be calculated using equation (5) and (6) based on the angle formed on each floor of the building during the ultimate deformation in the bending failure of the column.

For case $\mathrm{R}_{\mathrm{mu}}<\mathrm{R}_{\mathrm{y}}$

$$
\mathrm{F}=1+0,27 \frac{\mathrm{R}_{\mathrm{mu}}-\mathrm{R}_{250}}{\mathrm{R}_{\mathrm{y}}-\mathrm{R}_{250}}
$$

For case $\mathrm{R}_{\mathrm{mu}} \geq \mathrm{R}_{\mathrm{y}}$

$$
\mathrm{F}=\sqrt{\frac{2 \mathrm{R}_{\mathrm{mu}} / \mathrm{R}_{\mathrm{y}}-1}{0,75\left(1+0,05 \mathrm{R}_{\mathrm{mu}} / \mathrm{R}_{\mathrm{y}}\right)} \leq 3,2}
$$

\section{Methodology}

\subsection{Field observations}

Observation was done by examining reinforced concrete structures in Fisip Dean buildings (Fig. 4). The strength of the existing concrete is obtained by conducting nondestructive testing using the hammer test. Reinforcement bars used in the damaged structure are measured in the diameter of the reinforcement used, the type of reinforcement, and the length of the dispensing. The stirrups of reinforcement bar is measurement in the distance between the stirrups and the large angle and the length of the curve in the stirrups. The Dean building has a soft story. The building was originally 3 floors, and after the earthquake changed to 2 floors, the ground floor was totally collapsed.

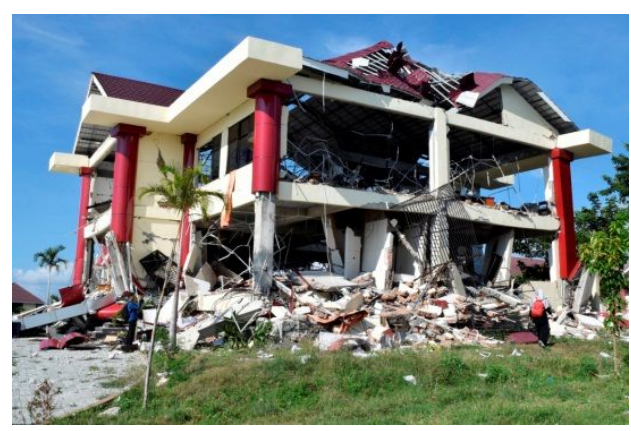

Fig. 4. The Dean Building of the Faculty of Social and Political Science (FISIP) of Tadulako University in PostEarthquake 2018

\subsection{Seismic capacity evaluation}

After observation and measurements then followed by seismic evaluation of the building. The evaluation of seismic capacity of the Dean Building was carried out based on the Standard for Seismic Evaluation of Existing Reinforced Concrete Buildings published by
The Japan Building Disaster Prevention Association using the second level evaluation method [9].

\section{Analysis and discussion}

\subsection{Description of building}

Another detail information on the building structure that required for calculation such as column size, column detail, reinforcement quality is obtained from detailed engineering design (DED) drawing of the Dean Building. Fig. 5 shows the first-floor plan of the building.

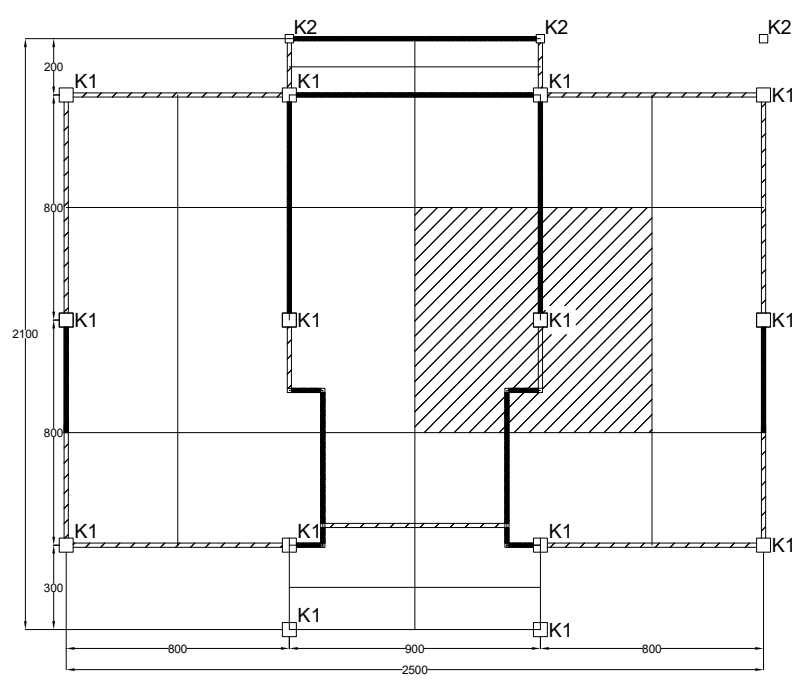

Fig. 5. Floor Plan and Floor Area of the Dean Building

\subsection{Seismic capacity of the building}

The seismic capacity of the Dean Building is evaluated only for the first floor, where the floor carries the most significant shear forces. The calculations are done in two directions, i.e., north-south direction (X direction) and east-west direction (Y-direction). In the analysis of the existence of brick walls ignored in calculations by assuming walls as non-structure components. The seismic capacity of the building is stated in the relationship between the strength index and the ductility index, as shown in Fig. 6.a for the north-south direction and Fig. 6.b for the east-west.

Fig. 6.a shows the phase collapse of the North-South direction column. The building has a total strength index of 0.379 . At the index of ductility 0.8 , the building suffered the collapse of the column before the plastic boundary by reducing the strength index by 0.125 . The collapsed column in the 0.8 ductility index is a sliding column. This column has a sliding collapse because there is a brick wall that curbs so that it is a short column with a net height of 1.8 meters. The collapse of this column caused the building to drastically decrease its strength index so that the building's strength index became 0.154 . The decline in this strength index is likely the reason why it collapsed when it was shaken by the massive earthquake. Furthermore, on the index of ductility 1.14 , the building again underwent a collapse 
of the column by reducing the strength index to 0.205 . Furthermore, the building's 1.84 ductility index underwent a collapse of the column by reducing the strength index to 0.147 . The building continues to experience the collapse of the column until all the columns collapse on the ductility limit of 3.2.

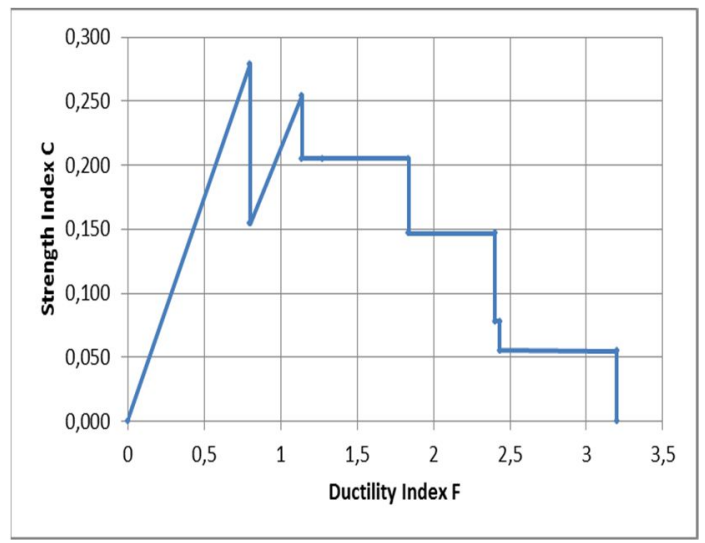

a. C and F Relations North-South

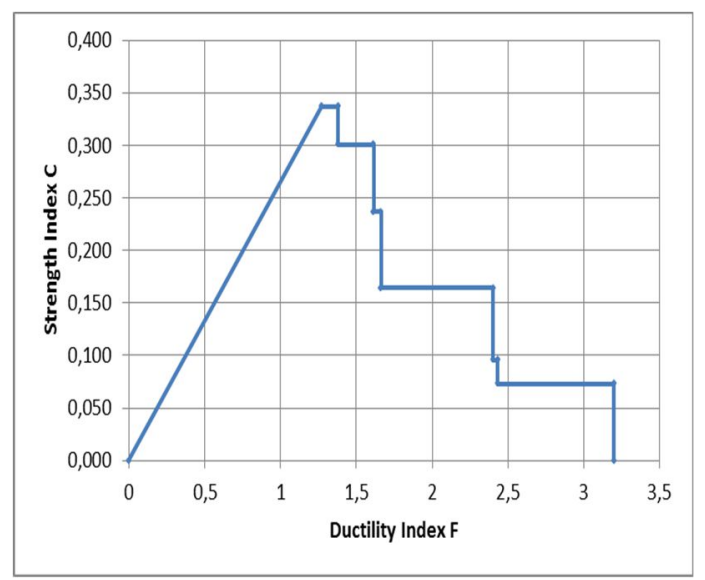

b. C and F Relations East-West

Fig. 6. C and F Index Relationship Graphs

Fig. 6.b shows the phase of collapse of the column east-west direction. The building has a total strength index of 0.337 . At the index of ductility 1.38 , the building suffered a collapse of the column by reducing the strength index to 0.301 . The type collapse column is a bending collapse. Most of the columns on the eastwest are experiencing bending collapse. At the next ductility index, the building continues to experience the collapse of the column until all the columns collapse at the index limit of the ductility 3.2.

\subsection{The collapse of the building}

The results of observations in the field showed that the Dean building was experiencing the collapse of the Palu post-earthquake 2018. The quality of the concrete is relatively low, and the reinforcement details do not conform to standards.

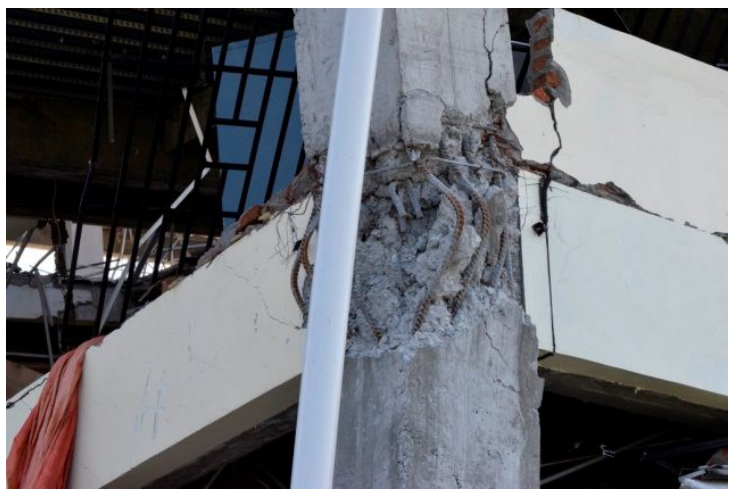

Fig. 7. The Damage in The Column Beam Connection

Fig. 7 shown that the consequences of not being properly installed at the join of beams and columns resulted in the main reinforcement of the column experiencing bent (broken). The size of the existing stirrups and curve is insufficient. The width dimensions of the beam should be designed smaller than the column, and column dimensions should be designed more strongly than beams. It is aimed at the main reinforcement of the beam to be restrained by the main reinforcement of the column. Also, the column beam join should be mounted in the field as the main reinforcement of the column to avoid damage after receiving the earthquake load. Based on the floor plan, the Dean Building of the Faculty of Social and Political Science of Tadulako University has a large column spacing of $9 \mathrm{~m}$ and $8 \mathrm{~m}$.

\subsection{Mitigation efforts}

In the earthquake-prone area for reinforced concrete buildings is recommended to use in minimum diameter $10 \mathrm{~mm}$ for reinforcement bar (D10) and the quality of concrete K-300 (fc' $25 \mathrm{MPa}$ ). Rainwater drain pipes should not be entered into the column because it will reduce the column cross-section so that the column strength will also decrease. Based on SNI 2847:2013 [10], the length of the main reinforcement of the beam to the column is $12 \mathrm{~d}$ with a curvature of $90^{\circ}$. Overlapping distance on a major reinforcement connection is $40 \mathrm{~d}$. The length of the stirrups latch is $6 \mathrm{~d}$, with a curve of $135^{\circ}$ [10]. The distance between the columns in the building should not be too large for the building to become more rigid, so it is expected to withstand the earthquake load.

\section{Conclusion}

The results of the analysis using Japanese standards [9] on the seismic capacity of the Dean Building of the Faculty of Social and Political Science of Tadulako University is relatively small. This is seen from the value of the strength index, and the ductility of the building is small. Therefore, the building was not able to withstand the burden of the earthquake and resulting in the building collapse. 
The building also has not fulfilled the requirements of the Indonesian national standard [10]. The results of observation in the field by conducting non-destructive testing using the hammer test obtained the quality of concrete material relatively low and the failure of the column beam connection due to insufficient reinforcement resulting in a building experiencing a collapse.

\section{References}

1. Gavin P. Hayes, et al. 2016. Tectonic Summaries of Magnitude 7 and Greater Earthquakes from 2000 to 2015.

2.USGS.2018.https://earthquake.usgs.gov/earthquakes/ browse/significant.php [diakses 13 November 2018]

3. Tirto. 2018. https://tirto.id/bnpb-kerugian-ampkerusakan-gempa-di-sulteng-capai-rp1382-triliunc8dX [diakses 8 Desember 2018]

4. Tim Revisi Peta Gempa Indonesia, Peta Hazard Gempa Indonesia 2010 Sebagai Acuan Dasar
Perencanaan dan Perancangan Infrastruktur Tahan Gempa. Jakarta: Kementrian Pekerjaan Umum (2010)

5. Panitia Teknik Standarisasi Bidang Konstruksi dan Bangunan. Pedoman Teknis Rumah dan Bangunan Gedung Tahan Gempa. Jakarta: Direktorat Jenderal Cipta Karya (2006)

6. Maidiawati, Agus, Jurnal Teknik Sipil ITB 23 (2016)

7.BNPB. 2019. (https://bnpb.cloud/dibi/laporan5) [diakses 8 April 2019]

8.Hamilton, Warren. Tectonics of the Indonesian Region. U.S. Geological Survey Professional Paper 1078 (1991)

9. The Japan Building Disaster Prevention Association (JBDPA), English Version, 1st. Standard for Seismic Evaluation of Existing Reinforced Concrete Buildings, 2001 (2005)

10. Badan Standardisasi Nasional. Persyaratan Beton Struktural untuk Bangunan Gedung SNI 2847:2013. Jakarta (2013) 